\title{
Section 706 of the Administrative Procedure Act Does Not Call for Universal Injunctions or Other Universal Remedies
}

\author{
John Harrison*
}

In Trump v. Pennsylvania, ${ }^{1}$ the Supreme Court faces the question whether the Administrative Procedure Act's provision governing scope of judicial review instructs courts to give universal injunctionsinjunctions telling the government not to apply a challenged agency action to anyone, not just the plaintiff. That provision, section 706 of title 5 of the United States Code, does not direct courts to give universal remedies. It does not address remedies at all. When it says that the reviewing court shall "hold unlawful and set aside" agency action that fails the tests it sets out, section 706 means that courts are not to follow the agency action in deciding the case. ${ }^{2}$ The APA addresses remedies, not in section 706, but in section 703. Section 703 in turn points to the remedies law associated with the forms of proceeding for judicial review that it identifies.

Part I of this Article briefly describes the debate about universal remedies. Part II elaborates the concept of universal remedies. That category includes but is not limited to universal injunctions like the injunctions given by the trial courts in Trump v. Pennsylvania and the travel ban case, Trump v. Hawaii. ${ }^{3}$ Part II also discusses the principal constitutional objection to universal remedies and the main response to that objection. Part III explores the text and structure of the APA, showing that section 706 does not address remedies, and that if it did, it would not authorize universal injunctions. ${ }^{4}$

\section{The Controversy over Universal Remedies}

The past few years have seen debate, in the courts and the academy, about remedies against the government that constrain its treatment of persons who are not parties to the case. In several high-profile cases, district courts ordered the government not to enforce a challenged policy

\footnotetext{
* James Madison Distinguished Professor, University of Virginia School of Law. Thanks to Sam Bray for comments. 1 No. 19-454 (2020).

2 "The reviewing court shall-(1) compel agency action unlawfully withheld or unreasonably delayed; and (2) hold unlawful and set aside agency action, findings, and conclusions found to be" inconsistent with several tests set out, including the requirement that agency action not be arbitrary or capricious. 5 U.S.C. $\$ 706$ (2018).

3138 S. Ct. 2392 (2018).

4 The reading of section 706 set forth here has important implications for the practice called remanding without vacating. See, e.g., Checkosky v. SEC, 23 F.3d 452 (D.C. Cir. 1994) (Silberman, J., and Randolph, J., differing on propriety of remanding action to an agency without vacating the agency's decision). I will not explore those implications here, other than to say that although section 706 does not support either of the main contending positions on that issue, it gives more support to the opponents than to the proponents of remand without vacatur.
} 
against anyone, whether or not a party. ${ }^{5}$ Professor Samuel Bray explored the issue in depth and criticized the practice. ${ }^{6}$

When one of the orders that forbade enforcement as to any party came before the Supreme Court in Trump v. Hawaii, the Court reversed on the merits and did not address the proper breadth of the remedy. Justice Thomas, in a concurring opinion, argued that "universal injunctions are legally and historically dubious. If federal courts continue to issue them, this Court is dutybound to adjudicate their authority to do so." The academic debate continues. ${ }^{8}$

The Supreme Court recently granted certiorari in Trump v. Pennsylvania, in which the district court issued, and the Third Circuit affirmed, an injunction directing the government not to enforce the regulations at issue as to anyone. The government's certiorari petition objected to the sweep of the injunction. ${ }^{9}$ That objection is part of a policy of resisting such decrees. In 2018, Attorney General Sessions issued guidelines to all Department of Justice litigators for cases involving nationwide injunctions. ${ }^{10}$ The guidelines hold that "Universal Vacatur Is Not Contemplated by the APA."11

\section{Universal Injunctions, Universal Remedies, and the APA}

This Part will elaborate the concept of universal remedies against the government, explain how universal remedies fit into the proceedings for judicial review referred to by section 703 of the APA, and describe the principal constitutional problem that such remedies raise

Trump v. Hawaii and Trump v. Pennsylvania involve judicial remedies now often called "universal injunctions." A universal injunction directs the government as defendant not to engage in some conduct, like enforcing a regulation, as to anyone. The district court in the travel ban

5 See, e.g., Texas v. United States, 809 F.3d 134, 187-88 (5th Cir. 2015) (approving nationwide injunctions against enforcement of Deferred Action for Parents of Americans and Lawful Permanent Residents program), affirmed by an equally divided Court, 136 S. Ct. 2271 (2016).

6 See Samuel L. Bray, Multiple Chancellors: Reforming the National Injunction, 131 HARV. L. REV. 417 (2017).

7 See 138 S. Ct. 2392, 2429 (2018) (Thomas, J., concurring). Justice Thomas relied on Professor Bray's work. See id. at 2427.

8 See, e.g., Mila Sohoni, The Lost History of the "Universal" Injunction, 133 HARV. L. REV. 920 (2020) (noting that universal injunctions were well known before the APA).

9 Petition for Writ of Certiorari at 32-35, Trump v. Pennsylvania, No. 19-454 (2020).

10 See Memorandum from the Attorney General, U.S. Department of Justice, Litigation Guidelines for Cases Presenting the Possibility of Nationwide Injunctions (Sept. 13, 2018). The guidelines do not take the position I do, that section 706 does not concern remedies at all. Instead, the guidelines say that courts should confine themselves to invalidating the concrete agency action before them. The concrete action may be, not a regulation, but the application of the regulation to the private party's conduct. If the agency action before the court is a rule itself, and not just its application to the private party, the court should set it aside only as applied, and not on its face. Id. at 7.

11 Id. 
case ordered the government not to apply the ban to anyone. In Trump v. Pennsylvania, the district court ordered the defendant agencies not to enforce the challenged regulation against anyone. The injunctions in both cases were universal in that they applied to all possible objects of the government decision at issue. For that reason, they involved the government's conduct with respect to many non-parties. In the travel ban case, the ban did not apply at all to Hawaii, which is already in the United States.

Universal injunctions are instances of the broader category of universal remedies. Another kind of universal remedy is deployed under a type of statute that is quite familiar in administrative law. Some statutes that provide for judicial review of agency action put the reviewing court in a position very similar to that of an appellate court. An appellate court's judgment operates directly on the legal effect of the lower court's judgment. For that reason, appellate review is called direct, as opposed to collateral, review. If an appellate court reverses the lower court, that act by itself eliminates the legal effect of the judgment being reversed, which otherwise would remain in operation.

When a statute creates that kind of judicial review of agency adjudication, any decree of the reviewing court is limited to the parties to the adjudication. Some statutes, however, create the appellate-review structure for agency regulations, which like laws usually apply to many people. If the statute authorizes the reviewing court to take the kind of step with respect to a regulation that an appellate court takes with respect to a lower-court judgment, overturning it entirely, the statute provides for a kind of universal remedy. The statutory provision for review of SEC rules, for example, authorizes the court to "set aside" the rule under review. ${ }^{12}$ If setting aside a rule works like setting aside a lower-court judgment, and deprives the action set aside of any legal effect, that provision enables courts to free all parties subject to a rule of obligations under it. ${ }^{13}$ That is a universal remedy. It is not a universal injunction, because it is not an order to the agency.

The APA has a place for both kinds of universal remedy, if they are available in the applicable form of judicial review, and it is important to see that the statute distinguishes between them. Section 703 of title 5 provides:

The form of proceeding for judicial review is the special statutory review proceeding relevant to the subject matter in a court specified by statute or, in the absence or inadequacy thereof, any applicable form of legal action, including actions for declaratory judgments or writs of prohibitory or

1215 U.S.C. $\$ 78 y(b)(2018)$.

13 I have not studied the SEC statute carefully enough to know whether it does enable the reviewing court to nullify an agency rule altogether. That some statutes work that way is a premise of many judicial decisions and much scholarship. I assume that some do, and give section $78 \mathrm{y}(\mathrm{b})$ as a possible example. 
mandatory injunction or habeas corpus, in a court of competent jurisdiction. . . Except to the extent that prior, adequate, and exclusive opportunity for judicial review is provided by law, agency action is subject to judicial review in civil or criminal proceedings for judicial enforcement. ${ }^{14}$

Section $78 \mathrm{y}$ of title 15 is a special review statute for the SEC. The Hobbs Act is a special review statute for several agencies, including the FCC. ${ }^{15}$

Injunctions against enforcement, like those at issue in Trump v. Hawaii and Trump v. Pennsylvania, are an applicable form of legal action other than a special review statute. Injunctive proceedings are structured like lawsuits against the government, not like appeals from a lower tribunal. An injunction against proceedings to enforce a regulation is an order to the government. It does not purport to undo the regulation the way the agency might revoke it. Although injunctions against enforcement and decrees reversing or setting aside agency action under special review statutes are distinct, both can constitute universal remedies. If a court under a special review statute sets aside a regulation that applies to parties other than the party seeking review, it gives a universal remedy. If the court in an injunctive proceeding tells the government not to enforce a rule against anyone, it gives a universal remedy.

The primary constitutional objection to universal remedies has mainly been discussed with respect to universal injunctions, but it can apply to the broader category. The objection is that universal remedies can go beyond vindicating the rights of the plaintiff, and so go beyond the Article III case or controversy the plaintiff has presented and that the court has power to decide. A central aspect of the debate over universal remedies turns on the possibility that only some of them raise that problem.

The first step in understanding the objection and its limits is to see how a court might give an order that remedies the harm to the plaintiff, although the order concerns the government's treatment of some third party. An example is Pierce v. Society of Sisters. ${ }^{16}$ That case involved an Oregon statute that required that parents send their children to public schools. The Society of Sisters operated a private school. The statute did not apply to the Society, but to its potential contracting partners. The Court found that the Society's economic interest made it a proper plaintiff to seek an injunction against enforcement of the law as to parents, who were not parties. ${ }^{17}$ The Court found that the statute's restriction on

\footnotetext{
145 U.S.C. $\$ 703$ (2018). Provisions of title 5 that derive from the APA are often referred to by the name of that statute, so section 703 is often called section 703 of the APA. That usage is not strictly correct, because title 5 replaced the APA as originally enacted, but it is common and well understood.

15 The Hobbs Act gives the reviewing court exclusive jurisdiction "to enjoin, set aside, suspend (in whole or in part), or to determine the validity of" the agency actions it refers to. 28 U.S.C. $\S$ 2342 (2018).

16268 U.S. $510(1925)$.

17 Id. at 535 .
} 
parents was unconstitutional, and approved an injunction entered by the lower court that prohibited enforcement against parents. Relief to the plaintiff ran through non-parties, but was justified by its benefits to the plaintiff.

The next step to a justification for universal orders is the possibility that the court might not be able to identify the specific third parties through whom harm to the plaintiff would come. In the travel ban case, Hawaii argued that the ban harmed it economically by keeping people from coming to the State, and that identifying potential visitors to Hawaii among all the people subject to the ban was not feasible. The only way to make sure to give Hawaii a remedy was to bar enforcement of the ban as to anyone. ${ }^{18}$ With that argument, the State sought to fit its case into a category familiar from equity: indivisible relief. When relief cannot be divided so as to affect only the plaintiff, equity principles often allow effects on third parties in the interest of a remedy for the plaintiff. The source of indivisibility can be difficulty in administering a more finegrained decree, as in the travel ban case. The source can also come from the physical effects of the defendant's conduct. If one neighbor claims that another's loud noise at night is a nuisance, an injunction against making the noise will affect all neighbors within earshot, not just the plaintiff.

Special review statutes raise the same constitutional issues insofar as they provide for universal remedies. A special review statute that enables a court to annul regulations altogether is subject to the objection that it goes beyond vindicating the rights of the plaintiff. A possible response is that relief to the plaintiff is indivisible from its effects on third parties for good practical reasons. I will not explore this important question further, because the main point of this article is that section 706 of the APA does not raise it. Section 706 does not call for universal remedies.

Universal remedies raise a problem under Article III when they take the courts beyond vindicating the rights of the parties before them. Justifying a universal remedy by its benefits to the plaintiff is an answer to that problem. That answer may not be adequate, and it will not be available in every case. If Congress has called for universal remedies, then the constitutional problem and possible responses to it must be addressed. The view that Congress has done so in section 706 appears to be widespread. Congress has not done so.

\section{Section 706 and Universal Remedies}

The argument that the APA calls for universal remedies in all cases involving judicial review of regulations may seem quite natural after the discussion of special review statutes that put the judiciary in a position 
like that of an appellate tribunal. That argument goes as follows: Some special review statutes contemplate that the court may "set aside" the agency action under review. When an appellate tribunal sets aside a lower tribunal's judgment, it renders that judgment inoperative. When a special review statute contemplates that the reviewing court will set aside a regulation, as opposed to an adjudication, it may contemplate one of the forms of universal relief discussed above: by setting aside the regulation, the court eliminates its effects as to everyone, plaintiff and nonparties alike. Section 706 tells courts to "hold unlawful and set aside" agency action that fails one of the tests it sets out. Therefore, when the agency action under review is a regulation and the regulation is unlawful, section 706 instructs the reviewing court to make the regulation legally null. Because section 706 applies to all judicial review, its command to set aside agency action is not confined to special review statutes, and applies in cases like Trump v. Pennsylvania, which involves an injunction and not a special review statute.

Section 706 does not tell courts to apply the remedy of setting aside agency action. It does not deal with remedial orders at all. When it says "set aside," it directs the court not to decide in accordance with the agency action. The remedial consequences of so treating an agency action depend on the form of proceeding, and so are governed by section 703 and the sources of law to which it points. In an enforcement proceeding, for example, to set the agency action aside is to treat it as legally ineffective, the way a court treats an unconstitutional statute as ineffective.

If section 706 did instruct courts to set aside agency actions the way they do in appellate-type proceedings under special review statutes, it still would not justify the kind of universal injunction at issue in Trump $v$. Pennsylvania. Injunctions are commands to agencies. They do not directly affect the legal status of regulations.

\section{A. Section 706 Does Not Authorize Remedies}

The argument that section 706 does not concern remedies has two components. The first is about its text, the second about the structure of the APA's judicial review provisions.

\section{The Different Senses of "Set Aside"}

When the APA was adopted, and today, a court can "set aside" another party's action in more than one way. As discussed above, when an appellate court reverses or vacates a lower court's judgment, it can be said to set that judgment aside. The appellate court engages in a juridical act that alters the legal consequences of another juridical act. Lowercourt judgments have binding effect unless disturbed. Reversal or vacatur eliminates that effect, causing the lower court judgment to be inopera- 
tive. This is the sense of "set aside" the Third Circuit relied on in Trump v. Pennsylvania. ${ }^{19}$

Those words can also refer to a court's decision to regard a purportedly valid juridical act as ineffective. That is what courts do when they find a statutory rule to be unconstitutional. According to the standard account of judicial review, the Constitution itself renders lower-level rules that conflict with it inoperative. That invalidity is found by the courts, not made. When a court finds a statutory rule unconstitutional, it does not issue an order purporting to reverse or vacate the statute. Instead, the court decides the case on the assumption that the unconstitutional statutory rule is not binding and is to be disregarded..$^{20}$ Any remedy the court gives runs to the defendant, not to the legislature.

In the years before the APA was adopted in 1946, courts and Congress sometimes used "set aside" to refer to a judicial finding of invalidity. Two well-known cases from the 1930s illustrate judicial usage. In Erie Railroad Co. v. Tompkins, ${ }^{21}$ Justice Butler in dissent invoked the "grave consequences liable to result from erroneous exertion of [the Court's] power to set aside legislation." 22 Justice Butler referred to a power, but he understood that it was exercised by disregarding unconstitutional statutes in the process of deciding cases. He pointed to the Court's "reluctance to consider constitutional questions," as a result of which "legislation will not be held invalid as repugnant to the fundamental law if the case may be decided upon any other ground." ${ }^{23} \mathrm{He}$ recognized that legislation was held invalid, that is found to be and not made to be invalid, and that such holdings were made in order to decide cases, and could be avoided if another ground of decision could be found. Justice Butler went on to point to the Court's practice of making sure to "indicate precisely the principle or provision of the Constitution held to have been transgressed, and fully disclose the reasons and authorities found to warrant the conclusion of invalidity." ${ }^{4}$ Invalidity was for Justice Butler a

19 See Pennsylvania v. President, 930 F.3d 543, 575 (3d Cir. 2019) ("[O]ur APA case law suggests that, at the merits stage, courts invalidate - without qualification - unlawful administrative rules as a matter of course, leaving their predecessors in place until the agencies can take further action. Congress determined that rule-vacatur was not unnecessarily burdensome on agencies when it provided vacatur as a standard remedy for APA violations." (citing Prometheus Radio v. F.C.C., 652 F.3d 431, 453-54 \& n.25 (3d Cir. 2011) (vacating procedurally defective rule and leaving the prior rule in effect); Council Tree Commc'ns, Inc. v. FCC, 619 F.3d 235, 258 (3d Cir. 2010) (same))). The Court of Appeals may not have noticed the difference between review under special review statutes that put the reviewing court in a position like that of an appellate tribunal, and a suit for an injunction against enforcement. The cases it cited were of the former kind; the case before it was of the latter.

20 See, e.g., Marbury v. Madison, 5 U.S. 137 (1803) (holding statutes that are inconsistent with the Constitution are invalid and courts treat them as legally ineffective).

21304 U.S. 64 (1938).

22 Id. at 87 (Butler, J., dissenting).

23 Id.

24 Id. 
conclusion reached on the basis of reasons and authorities, not a change in the legal landscape.

In another momentous case from the 1930s, Home Building \& Loan v. Blaisdell, ${ }^{25}$ the Court described an earlier Contracts Clause case as one in which "a statute which restricted the power of taxation which had previously been given to provide for the payment of municipal bonds was set aside." 26 Like Justice Butler in Erie, Chief Justice Hughes, writing for the Court in Blaisdell, had in mind the orthodox approach, in which invalidity is found, not made. In the sentence immediately before his use of "set aside," the Chief Justice described another earlier Contracts Clause case as one in which "a state law was found to be invalid." 27

Congress used "set aside" the same way in a 1937 statute that was spurred in large part by cases involving federal agencies. Congress that year did not expand the Supreme Court as President Roosevelt had requested, but it did act to constrain constitutional judicial review. A change to the jurisdictional statutes provided that only three-judge district courts were to issue any "interlocutory or permanent injunction restraining the enforcement, operation, or execution of, or setting aside, in whole or in part, any Act of Congress upon the ground that such Act or any part thereof is repugnant to the Constitution of the United States." 28 Congress's assumption that an injunction can set aside a statute rested on the orthodox account of judicial review. According to that account, courts find unconstitutionality and, when appropriate, give remedies like injunctions that reflect that finding. A court that issues an injunction based on a finding of invalidity can be said to set aside the relevant statute, but does not render the statute legally inoperative. Injunctions are orders to defendants. They can limit the enforcement of statutes, but they do not purport to alter the content of statutory law. An interlocutory injunction can be dissolved by the court that issued it, and a permanent injunction can be reversed by an appellate court. Courts cannot repeal or reenact statutes, but they can make and unmake orders to agencies. The three-judge court statute did not assume that a court can set aside a statute the way an appellate court sets aside a lower court's judgment.

The attitude of the bill's sponsors on this point need not be left to inference from the statute they prepared. The Senate Judiciary Committee's report on the bill had several statements reflecting the orthodox understanding of judicial review. The most striking is a quotation from an opinion by Justice Sutherland that is a classic formulation of the orthodoxy:

25290 U.S. 398 (1934).

26 Id. at 432 (citing Von Hoffman v. City of Quincy, 71 U.S. 535 (1867)).

27 Id. (citing Planters' Bank of Miss. v. Sharp, 47 U.S. 301 (1848)).

28 Act of August 24, 1937, ch. 754, sec. 3, 50 Stat. 751, 752. 
We have no power per se to review and annul acts of Congress on the ground that they are unconstitutional. ... [T] he power exercised is that of ascertaining and declaring the law applicable to the controversy. It amounts to little more than the negative power to disregard an unconstitutional enactment, which otherwise would stand in the way of the enforcement of a legal right. ${ }^{29}$

Besides quoting Justice Sutherland, the committee stated that "[n]o substantive power exists to review and nullify acts of Congress." 30 For the drafters of the 1937 three-judge court statute, "set aside" meant treat as non-binding.

2."Set Aside" and the Relationship Between Sections 706 and 703

When section 706 directs courts to set aside agency action, it thus might mean, not to decide in accordance with that action, including regarding it as legally ineffective. The structure of the APA confirms that section 706 uses "set aside" that way. Section 706 governs "scope of review." Section 703 governs "form and venue of proceeding for judicial review." It includes as forms of proceeding for judicial review special review statutes, other forms of action including habeas corpus, declaratory and injunctive proceedings, and civil or criminal enforcement proceedings. ${ }^{31}$

In several of those forms of proceeding, the court does not issue an order that purports to change the legal status of the agency's action at issue. When a court in an enforcement proceeding conducts review, finds that the agency action was unlawful, and sets it aside, the defendant prevails and the government loses. The court gives no affirmative remedy purporting to set aside the agency action. Declaratory judgments conclusively determine, but do not change, the parties' legal relations. If a court sets an agency action aside in the sense of regarding it as legally ineffective, a declaratory judgment may reflect that conclusion. The court might declare, for example, that an invalid regulation imposes no duty on a private plaintiff and gives the government no correlative right to compliance. ${ }^{32}$ A declaratory judgment can rest on the conclusion that an agency regulation is invalid, but it cannot bring that invalidity about, because it declares and does not alter legal relations.

29 S. REP. No. 75-963, at 3 (1937) (quoting Massachusetts v. Mellon, 262 U.S. 447, 488 (1923) (Sutherland, J.) (ellipsis not in the committee report)).

30 Id.

31 See 5 U.S.C. $\$ 703$ (2018).

32 Declaratory judgments "declare the rights and other legal relations of any interested party seeking such declaration" in a "case of actual controversy" within the issuing court's jurisdiction. See 28 U.S.C. $\$ 2201$ (2018). Invalidity is not itself the legal relation of a party. The relation of a private party subject to an invalid regulation that purports to govern the party's conduct is privilege or liberty, correlated with a no-right on the part of the government. 
Several other forms of proceeding in which judicial review takes place do involve affirmative remedies that change legal relations, but not a remedy that purports to change the legal status of the agency action at issue. When judicial review enables a habeas petitioner to prevail, the court directs the defendant to release the petitioner, but issues no other order. When a private plaintiff seeks and obtains an injunction against the institution of enforcement proceedings, the injunction is directed to the enforcement official. It does not operate the way a judgment of reversal operates on the judgment below.

Section 706 applies in all the forms of proceeding contemplated by section 703. Its directive to set aside agency action must thus be such that a court can comply with it in any form of proceeding. A court in an enforcement proceeding, in a declaratory proceeding, in habeas, or in a suit for an injunction against enforcement proceedings, cannot comply with a directive to issue an appellate-type order purporting to undo what the agency has done. In all those proceedings, and in all proceedings covered by section 703 , the court can comply with a directive not to decide in accordance with the agency action. ${ }^{33}$

Section 706 does not call for any remedy, universal or limited. ${ }^{34}$

\section{B. If Section 706 Directs Courts to Give a Remedy, It Does Not Call for Universal Injunctions}

Suppose the foregoing argument is wrong, and section 706 does direct courts to give a remedy that sets aside agency action the way an appellate court sets aside a lower-court judgment. If that were the correct reading of section 706, it would not call for universal injunctions like that issued in Trump v. Pennsylvania. That case did not arise under a special review statute that creates an appellate-type proceeding. It was a suit in district court with the agencies as defendants, in which the plaintiff sought an injunction against enforcement of a regulation. Injunctions against enforcement are not like appellate judgments of reversal. Reversal by an appellate court changes the legal status of the lower court's judgment. An injunction against enforcement of a regulation rests on the

\footnotetext{
33 The slightly cumbersome formulation I use, that section 706 tells the court not to decide in accordance with the agency action, reflects the differences among proceedings for judicial review. In an enforcement proceeding, for example, not deciding according to the action means treating it as legally ineffective. Under an appellate-type special review statute, not deciding according to the action means making it ineffective.

34 The committee reports on the APA are consistent with this account of the scope of judicial review provision, and count against the reading according to which it directs that a remedy of setting aside be given. Both reports, in discussing that part of the judicial review provision, paraphrase it by saying that the court is to hold the agency action unlawful, without including setting aside. See S. REP. No. 79-752, at 27 (1946); H.R. REP. NO. 1980, at 44 (1946). If the report drafters had thought that "set aside" added a directive about remedies, they likely would have included it. If they thought that it confirmed that unlawful agency action was not to be implemented, they had less reason to do so.
} 
conclusion that the regulation is already invalid. An anti-enforcement injunction cannot bring that invalidity about, because invalidity must be found before the injunction can issue. Injunctions against enforcement cannot vacate rules, so if section 706 directs courts to vacate agency action it does not instruct them to give anti-enforcement injunctions.

Judges and others experienced in administrative law may miss this difficulty because they may not have in mind the differences among the forms of proceeding for judicial review. Some of those forms of proceeding do put the reviewing court in a position like that of an appellate tribunal. Some do not, and the form of proceeding in Trump v. Hawaii does not. $^{35}$

Section 706 does not call for universal remedies. 